Chirurgia (2020) 115: 563-578

No. 5, September - October

Copyright@ Celsius

http://dx.doi.org/10.21614/chirurgia.115.5.563

\title{
Pregnancy and Colorectal Cancer, from Diagnosis to Therapeutical Management - Short Review
}

\author{
Dragoș Predescu', Marius Boeriu', Adrian Constantin'1, Bogdan Socea², Dan Costea ${ }^{3}$, Silviu Constantinoiu' \\ ${ }^{1}$ Center of Excellence in Esophageal Surgery, "Sf. Maria" Clinical Hospital, Carol Davila University of Medicine and Pharmacy, \\ Bucharest, Romania \\ ${ }^{2}$ Carol Davila University of Medicine and Pharmacy, Department of Surgery, "Sf. Pantelimon" Emergency Clinical Hospital, \\ Bucharest, Romania \\ ${ }^{3}$ Department of Surgery, Emergency County Clinical Hospital, Ovidius University of Medicine and Pharmacy, Constanta, Romania
}

Corresponding author:

Dragos Predescu, MD, PhD

Department of Surgery

St. Mary Hospitall

University of Medicine and Pharmacy

Carol Davila, Bucharest, Romania

E-mail: drpredescu@yahoo.com

Abbreviations:

CRC - colorectal cancer;

CIN - chromosomal instability;

MSI - microsatellite instability,

HNPCC - Hereditary Non-Polyposis

Colon Cancer;

FAP - Familial Adenomatous Polyposis;

AFAP - Attenuated Familial Adenomatous

Polyposis;

PgRs - progesterone;

Ers - estrogen;

IBD - Inflammatory bowel disease;

UC - ulcerative colitis;

CD - Crohn disease;

FOBT - fecal occult blood testing.

\section{Rezumat \\ Graviditatea și cancerul colo-rectal, de la diagnostic la managementul terapeutic - scurt review}

Cancerul colorectal (CRC) este considerat ca una din cele cele mai frecvente malignităti, afectând una dintre 20 de persoane din zonele cu standard socio-economic ridicat, dar cazurile de cancer digestiv în timpul sarcinii sunt rare. Din punct de vedere etiologic, CRC reprezintă o entitate indusă pe de o parte de factori de mediu iar pe de altă parte de factori genetici sau, deloc rar, de combinația lor. Dificultatea diagnosticării cancerelor digestive în sarcină este consecința unei simptomatologii adesea mascată de semne şi simptome care pot fi atribuite sarcinii. Esențială în ceea ce priveşte evaluarea stadializării TNM în $\mathrm{CRC}$, tomografia computerizată (CT) rămâne obiectul a numeroase dezbateri şi "dispute" medicale. În ultimii 40 de ani, CT-ul a fost contraindicat la gravide din cauza prezumției unor efecte teratogene şi cancerigene asupra fătului. Rezonanța magnetică (RMN) în sarcină este de preferat oricărei alte metode de investigare care utilizează radiații ionizante. Planul de tratament al CRC trebuie să țină seama de interesele a două persoane, mama şi fătul, astfel încât „interesul” unuia să nu-l afecteze pe celălalt, respectând o axiomă: pentru mamă, tratament cât mai curând posibil după naştere respectiv, pentru făt, temporizarea terapiei până când acesta este viabil. Neoplazia colorectală este, în general, o patologie predominant chirurgicală în momentul descoperirii bolii, mai ales în condițiile unei 
complicații majore care nu lasă timp pentru o alternativă terapeutică (obstrucție, perforație, sângerare semnificativă). Un protocol oncologic de tip chimioterapic este o opțiune preferată la cazurile cu malignitate avansată, metastatică.

Cuvinte cheie: cancer colorectal, sarcină, management terapeutic

\begin{abstract}
Colorectal cancer (CRC) is one of the most common human malignancies, affecting one of 20 persons in areas with high socio-economic standard but cases of digestive cancers during pregnancy are rare. From an etiological point of view, CRC represents an entity induced on the one hand by environmental factors and on the other hand by genetic factors or, not rarely, by their combination. The difficulty of diagnosing digestive cancers in pregnancy is the consequence of a symptomatology often masked by signs and symptoms that can be attributed to pregnancy. Essential in terms of assessing the staging of TNM in CRC, CT remains the subject of numerous debates. Over the last 40 years CT has been contraindicated in pregnant women due to teratogenic and carcinogenic effects on the fetus. Pregnancy MRI method is preferable to any other method of investigation that uses ionizing radiation. The CRC's treatment plan must take into account the interests of two people, the mother and the fetus, so that the "interest" of one does not affect the other, respecting an axiom: for the mother, treatment as soon as possible after birth, respectively, for the foetus, delaying the therapy until it is viable. Colorectal neoplasia is, in generally, a predominantly surgical pathology at the time of disease discovery, especially in conditions of a major complication that leaves no time for a therapeutic alternative (obstruction, perforation, significant bleeding). A chemotherapy-type oncology protocol option is preferred for cases with advanced, metastatic neoplasms.
\end{abstract}

Key words: colorectal cancer, pregnancy, therapeutic management

\section{Introduction}

Cases of digestive cancers during pregnancy are rare, their reporting being sporadic. Because nowadays the pregnancy often occurs at ages between 30-39 (even between 40-49 years old), it could explain the increasing frequency association of cancers and pregnancy. Miscellaneous population trials (1-5) notes in the last 3-4 decades an explosive growth of some digestive neoplasms, especially by involving of some age groups from the fertile period of the woman between 15-49 years. By analogy with breast cancers, digestive cancers in pregnancy are defined as cancers diagnosed during pregnancy and in the first year postpartum. From the multitude of digestive visceral sites, the most frequent neoplasms appear to be of the stomach, colon and rectum, only in exceptional cases liver and pancreatic cancers. Also, paraclinical evaluation of these patients is difficult, as the pregnancy trimester is an important indicator of the opportunity of a certain investigation. Precaution related to fetal involvement in the indication of invasive exploration (imaging, endoscopic, etc.) also delays the diagnosis. That is why digestive cancers are diagnosed in pregnancy in advanced stages, usually in the complication phase: occlusion, hemorrhage, perforation or cachexia.

The diagnostic and treatment protocols applied to the non-pregnant patient are not similar to those in pregnancy, most often a multidisciplinary approach, involving the association of medical-obstetrician-surgeon- 
gastro-enterologist-pediatric neonatologistpsychologist specialized in oncology, together with the patient and his family will be able to define the correct and balanced approach of the optimal therapeutic plan.

Overall CRC incidence data shows a modest decrease since the 1980s in industrialized countries and a slow but steady growth in poorly developed countries (eg in the USA since 1998 the incidence of CRC in women has decreased by about $2.2 \%$ per year) $(6,7)$. This decrease is essentially attributed to the CRC screening techniques $(8,9)$. There was no specific incidence of CRC in pregnant women compared to that in the general population. Consequently, the incidence of CRC in fertile women is consistent with that of CRC in the general female population for decades of appropriate age ('20-29, '30-39 and '40-49 years old) $(10,11)$. In the US female population covering the three decades above, it was noted that, in contradiction with the decreasing level of CRC incidence, the statistical data shows a constant growth of CRC of $1.6 \%$ per year since 1992 (Fig. 1), especially among the non-Hispanic white population $(12,13)$. The apparent cause of this evolution is due to the increase of the age for pregnancy, a series of socioprofessional considerations pushing in time the period of pregnancy in the $3^{\text {rd }}$ and even $4^{\text {th }}$ decades of the life of the future mother.

The first 245 cases were reported between 1842-1995, and between 1996-2004 30 new cases are reported, which almost doubles the incidence of CRC in pregnant women (14-17). In the unitary group of patients, in the three decades of age, the peak of the incidence appears in the patients of 31 years old. A particular feature of colo-rectal neoplasia in pregnant women compared to the general population is the tumor site. Thus, if in the general population the rectum comprises about $25-30 \%$ of the total CRC, in the case of pregnancy there is a counter-balance, the subperitoneal rectum being interested in most cases (18) (about 85\%). This atypical behavior raises questions about the etiology of neoplasia. Firstly, a different biological behavior

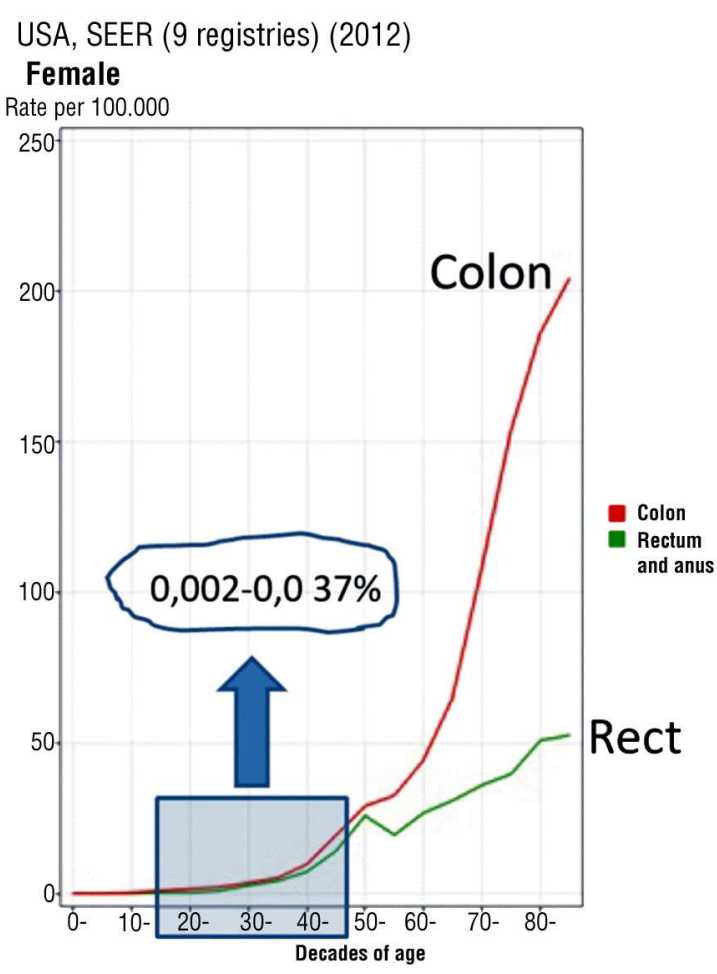

Figure 1. The evolution of CRC incidence in the 20-49 decades. There has been a steady annual growth since1992 (World Health Organization)(1)

of CRC tumors during pregnancy is suggested. Most likely, however, the cause is the discovery of the tumor much easier at routine gynecological control during pregnancy, either due to the accentuation of the symptoms by the tumor growth together with the compression on the rectum in pregnancy.

\section{Etiology}

\section{Environmental and genetic factors}

From an etiological point of view, CRC represents an entity induced on the one hand by environmental factors and on the other hand by genetic factors or, not rarely, by their combination. From the genetic perspective, based on the causes involved in the emergence of CRC, there are three major types: sporadic CRC (60-70\%), family CRC (30-40\%), hereditary CRC (genetic diseases 4-6\%) (19). Sporadic CRC is rarely encountered under the age of 50. As a result, the cases reported in literature of pregnancy 
associated with CRC meet the conditions of family CRC, respectively genetic. Family type associates increased risk of genitors developing CRC (doubles if first-degree relatives develop CRC, especially under the age of 50), while the genetic type associates syndromes known for genetic material abnormalities: HNPCC (Hereditary NonPolyposis Colon Cancer or Lynch syndrome), FAP (Familial Adenomatous Polyposis), AFAP (Attenuated Familial Adenomatous Polyposis), APCI 1307K, Peutz-Jehger's Syndrome, MAP (MYH associated Polyposis), Juvenile Polyposis, Hereditary Polyposis. The various syndromes (FAP, JPS, Peutz-Jeghers, Cowden, Bannayan-RileyRuvalcaba) have high rates of de novo mutations $(25-30 \%)(20,21)$, while LS associates de novo mutations in MMR at a reduced frequency $(0,9-5 \%)(22)$.

\section{The influences of steroid receptors}

The hypothesis of the involvement of progesterone (PgRs) and estrogen (Ers) receptors in CRC pathogenesis in pregnant women is extremely interesting. It was found $(23,24)$ that at approx. $20-54 \%$ of CRC reports the presence of Ers, as other authors identify PgRs in about $42.8 \%$ of cases. It is thus suggested that there is a link between high levels of estrogen and progesterone in pregnancy and the stimulation of CRC proliferation. A second consequence would be the discovery of advanced stage neoplasia, due to the high titres of sex hormones.

\section{Cox-2 enzyme}

Cox-2 enzyme also find in pregnant women the essential role of the Cox-2 enzyme and derivatives in the early stages of pregnancy (ovulation, fertilization, implantation, and decidualisation) but also in the other stages of pregnancy. Because high levels of Cox-2 are encountered in CRC, in was made a hypothesis (25) of an interrelation between the two phenomena.

In addition to genetic involvement, other etiological mechanisms of CRC, environmental or individual, behavioral are incriminated.

\section{Obesity}

It is a major risk factor especially for hormoneactive women in the pre-menopausal period compared to the post-menopausal one. Because the rate of obesity cases has seen a spectacular increase in the last three decades in the industrialized countries $(26,27)$, the causal-effect link is defined in increasing the incidence of CRC at young age, in the fertile period. The mechanism by which obesity induces tumor development, respectively the latency period between aggression and tumor onset, remains unclear. The corroboration of type 2 diabetes and obesity and also the significant increase of diabetes in young adults certify the role of risk factor of diabetic disease in the onset of CRC $(28,29)$.

\section{Eating habits}

Eating habits particular to young people in the USA, tripling the fast-food consumption from the 1970s until now, a supercaloric and rich in meat diet, especially in children, makes it plausible that the increased CRC incidence in young adults may be the consequence of this eating behavior (13, 30-32). On the other hand, the consumption of milk has shown a protective effect. Other behavioral factors such as alcohol use and smoking are associated with increased risk of CRC $(33,34)$ in young patients.

\section{Inflammatory bowel disease}

Inflammatory bowel disease (IBD), ulcerative colitis (UC) and Crohn disease (CD), are well known to be premalignancies in patients with long-term disease, of at least 8-10 years (about $2 \%$ of CRC) (35-37). The presence of IBD in the pregnant woman is similar to the incidence in the general population. The occurrence of CRC in pregnancy is reported precisely on this background of long evolution of the disease (about 15-20 years - risk of occurrence of 2-3 times higher than in the population general) (38).

\section{Pathological anatomy and carcinogenesis}

The most common colorectal cancers in pregnancy are epithelial, 90\% adenocarcinomas and 10\% mucinous adenocarcinomas; the rest are considered rare types $(39,40)$ 
Table 1. The main histopathological types of colorectal cancer [Hamilton \& all (68) WHO Classification of Tumours of the Digestive System)

\begin{tabular}{l}
\hline Histopathologic Types of Colorectal Carcinoma - World Health \\
Organisation Classification \\
\hline Adenocarcinoma, NOS (not otherwise specified) \\
\hline Mucinous adenocarcinoma (colloid) (> 50\% mucinous) \\
\hline Signet ring carcinoma (> 50\% signet ring cell) \\
\hline Squamous cell carcinoma (epidermoid) \\
\hline Adenosquamous carcinoma \\
\hline Small cell carcinoma (oat-cell) \\
\hline Medullary carcinoma \\
\hline Undifferentiated carcinoma
\end{tabular}

Other types (Micropapillary carcinoma, Serrated adenocarcinoma,

Cribriform comedo-type adenocarcinoma)

(Table. 1). Interesting to note, however, is the specificity of the young adult for rare types such as various carcinoids or colorectal lymphomas. Especially in young women, including pregnant women, colonic carcinoid, squamous rectal cancers and "transitional cell like" rectal cancers are reported (41) (Fig. 2). Histo-carcinogenesis of CRC is not yet fully elucidated. The evolution towards neoplasia crosses the known adenoma / polyp - low / high dysplasia - invasive carcinoma-like lesion cascade (42-44) (Table. 2).

In the histological criterion of evaluation

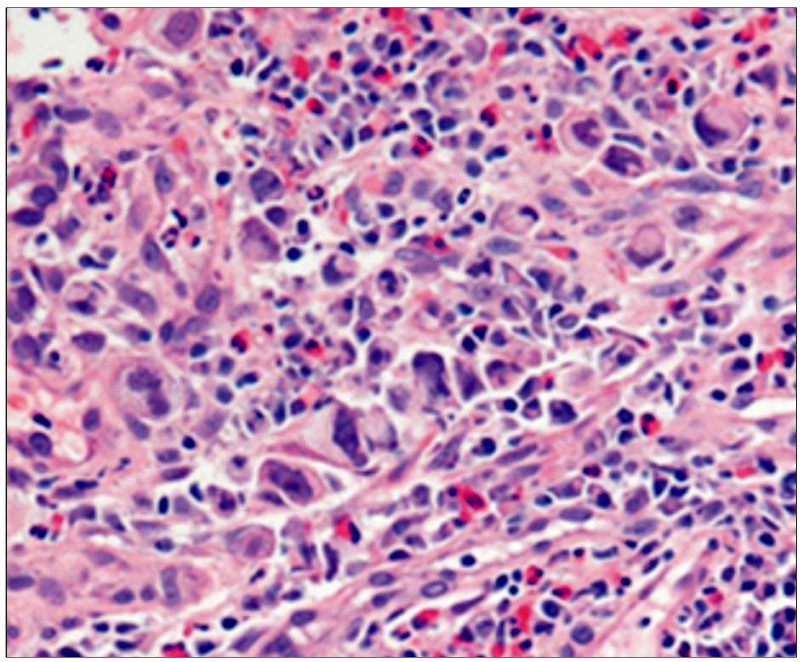

Figure 2. Histopathologic slide (magnification $\times 40$ hematoxylin and eosin) suggestive appearance for poorly differentiated, signet ring cell carcinoma CRC in pregnant woman (collection of the clinic)
Table 2. Vienna classification of gastrointestinal epithelial neoplasia and the sequence of evolution towards neoplasia (Schlemper RJ \&all) (74)

\begin{tabular}{ll}
\hline Category & Diagnosis \\
\hline Group 1 & Negative for neoplasia/dysplasia \\
\hline Group 2 & Indefinite for neoplasia/dysplasia \\
\hline Group 3 & Mucosal low grade neoplasia - Non invasive \\
& Low grade adenoma/dysplasia \\
\hline Group 4 & Mucosal high grade neoplasia - Non-invasive \\
Subgroup 4.1 & - High grade adenoma/dysplasia \\
Subgroup 4.2 & - Non-invasive carcinoma (carcinoma in situ) ${ }^{*}$ \\
Subgroup 4.3 & - Suspicion of invasive carcinoma \\
\hline Group 5 & Invasive neoplasia \\
Subgroup 5.1 & - Intramucosal carcinoma \\
Subgroup 5.2 & - Submucosal carcinoma or beyond \\
\hline *Non-invasive indicates absence of evident invasion. \\
'Intramucosal indicates invasion into the lamina propria or muscularis mucosae.
\end{tabular}

of neoplasia and, of course, for prognosis, the tumor differentiation type (grading) has a major importance, being considered an independent element of evaluation (45-49) by the World Health Organization: Low Grade/High Grade. Surbone et al (50) report in pregnant women a higher frequency of poorly differentiated and undifferentiated colorectal tumor or the presence of mucinous tumors. Additional specific histological assessment data of the tumor in the pregnant woman such as lymphatic invasion, vascular or perineural invasion, aneuploidy, etc. are missing in various studies, making a consistent assessment impossible, most probably due to the lack of a convenient statistical pool.

\section{Clinical diagnosis}

Clinical manifestations of CRC in pregnancy are masked by characteristic signs of pregnancy, all the more present as the pregnancy approaches the term: diffuse abdominal pain, meteorism, constipation, physical asthenia, possible rectal bleeding. The consequence will be the ignorance of the symptoms and the avoidance of the consultation with a doctor, with the progression of the neoplastic disease so that, most often, the diagnosis will reveal CRC in an advanced phase. Often, even the doctor can neglect these manifestations, putting them on account of pregnancy-specific complications (51). As a result, the physician 
should be alert to any new signs/symptoms, especially its persistence in pregnancy, and to consider the possibility of another pathology, such as CRC. Other less common manifestations would be unnatural weight loss, nausea and/or vomiting, malaise. Cancer of the right colon are hemorrhagic, usually with small but chronic bleeding (occult bleeding), leading to unexplained anemia, can only be detected by specific tests $(16,52)$. In comparision, cancer of the left colon are causing most often stenosis, are small in size, causing transit disorders in the form of a constipation that does not respond to treatment, with subocclusive syndrome or even intestinal obstruction. Exceptionally, König-type manifestations may occur. Bleeding often appears dark or marooncolored and may be mixed with stool. Distal (rectal) neoplasms are rarely occlusive, the main manifestation usually is bleeding with a characteristic aspect: partially degraded blood of hematochezia, mixed with stool or red blood or blood clots before or at the end of defecation, possibly associated with rectal tenesms. This should not be confused with bleeding from hemorrhoids, often present and with a noisy symptomatology in pregnancy.

In advanced CRC, metastatic, weight loss, anorexia, physical asthenia, poor health, constitute a symptomatic tetralogy specific to neoplastic cachexia.

Objective clinical examination is mandatory. During the inspection, the neoplastic impregnation can be found and, in the conditions of a complicated tumor, most commonly by perforation, a typical presentation is observed for an acute abdomen. At the palpatory examination, in the case of the right colon tumors, a tumor localised in the right fossa and right flank may be detected. On the other hand, as the pregnancy progresses. the maneuver can be made more difficult. In the left colon the tumor is most often hardly detectable. The identification of a distended colon, confirmed by percussion, accompanied by abdmonial pain, spontaneous or after palpation, may suggest a partial ot total obstruction. However, the clinical interpretation is not easy in pregnant women, especially at an advanced age of pregnancy. It is also difficult to identify signs of advanced neoplasm (hepatomegaly, ascites, carcinomatosis) or the Sister Mary Joseph sign (palpable umbilical metastasis). Vaginal and rectal examination (53) allow the identification of any lesions, including tumors, up to about 8-10 cm from the anus. Associated with vaginal examination, bidigital palpation of the recto-vaginal septum provides information about the anterior extension of the rectal tumor.

\section{Evolution and complications}

The occurrence of CRC complications in pregnant women causes a poor prognostic factor, immediately (vital) and also on a long term, both for mother and fetus. Quite often, the appearance of a complication is relevant for the diagnosis, in the conditions of a completely asymptomatic or at least non-specific evolution, as is the case with the pregnant women. Known complications of advanced CRC such as subocclusive/occlusive syndromes, compression phenomena or tumor invasion on neighboring organs with the establishment of internal fistulas or juxtatumoral or diastatic perforation can be found in pregnant women. Tumor perforation in the large cavity with diffuse fecal peritonitis is extremely severe and with an unfavorable prognosis for both mother and fetus. Chronic bleeding is not considered an evolutionary complication; only severe bleeding, externalized as lower digestive hemorrhage (hematochesis) being considered the mildest of the evolutionary complications of colon cancer. Neoplastic metastases are evidence of late-stage disease: lymph node and liver metastases, peritoneal carcinomatosis and carcinomatous ascites, and, less frequently, metastases to the lungs, bones, and ovaries. In the pregnant woman, acute symptoms of neighboring organs may appear, like acute cholecystitis or acute appendicitis, revealing the real diagnosis.

\section{Paraclinic Diagnosis}

\section{Screening tests}

In many countries, in last years, fecal occult 
blood testing (FOBT) through the Haemoccult test in pregnant women is common use. The test is more specific for left colon cancers and can cause false positive and false negative results (consumption of red meat, broccoli, iron medication, aspirin or derivatives, anticoagulants, etc.) (54-57). Even in ideal conditions, only $5-10 \%$ of patients tested were found to have CRC and another 20-30\% were found to have adenomatous polyps. The false negative results keep the patients in observation for the repetition of the method, and the false positive results are confirmed by the extension of the explorations. When possible, the pregnant woman enters a surveillance and reconfirmation program through a new test and is subsequently further investigated $(58,59)$.

\section{Laboratory tests}

Without offering a diagnosis of certainty, they highlight changes that suggest a neoplastic pathology: unexplained chronic anemia (without another detectable cause), leukocytosis resulting from tumor superinfection and increased inflammatory indices (ESR, fibrinogen), increased alkaline phosphatase, aminotransferases and bromsulfaphtale retention (liver metastases is suspected), high levels of alkaline phosphatase concomitant with those of calcium (suspicion of bone metastases).

Immunological tests (carcinoembryonic antigen - ACE, a-fetoprotein, CA 19-9) are lacking in specificity, having no diagnostic value in the early stages, but their role is gaining importance in postoperative oncological monitoring (60-63). Currently, their value is normal in pregnant women, not being influenced by pregnancy, or there is only a slight increase, without pathological significance (64). However, high levels of tumoral markers are correlated with a poor prognosis. After complete colic resections, the values should normalize. However, persistent high values suggests that the surgery was not curative, insufficient and, of course, overestimated. Return to normal values after surgery, followed after a while by a significant increase, suggests recurrence $(65-67)$.

\section{Imaging Techniques}

\section{Barium enema}

Radiological examination of the lower GI is used very successfully in the diagnosis of CRC but the pregnant woman represents a particular situation that limits the medical indication of this method only in exceptional cases. Irigography is criticized because of the mutagenic, teratogenic and carcinogenic effect of ionizing radiation. The appearance of the side effects above depends on the dose administered (measured in cGy), the conformational structure of the pregnant woman, the trimester of pregnancy, the treatments administered, etc. Current data recommends avoiding radiation greater than 5-10 cGy. Up to this irradiation threshold, the risks are associated with a low level of mutagenicity (stochastic biologic effects) and has no "non-stochastic" type effects (malformations, developmental pathologies) $(68,69)$. The average dose of irradiation per case is only 0,3 cGy, well below the recommended threshold for pregnant women. However, in the first trimester, in fact the most important and risky period for the fetus, parsimony is recommended in the indication for barium enema. The diagnostic sensitivity of the method is about $83 \%$, slightly lower than that of colonoscopy (70). A defect of the technique is due to the particular situation in pregnant women, especially in the advanced stages of pregnancy, altering the diagnostic interpretation by masking and possibly displacing the colon and/or tumor. Barium enema also has obvious advantages: cheap, less invasive and safer compared to colonoscopy (extremely low perforation risk - about 1 per 25000 examinations) (71).

\section{Endoscopy}

Endoscopy (rectosigmoidoscopy, colonoscopy) allows direct, macroscopic diagnosis and by direct biopsy sampling of the lesion. The risks of the method are not to be neglected $(72,73)$ : placental abruption as a consequence of luminal insufflation with pressure on the uterus, various fetal injuries secondary to hypotension or maternal hypoxia during 
exploration by deep sedation, teratogenic effects due to the administred medication, enteral perforation due to difficulty technique, etc. In a study on 192 cases, to minimize maternal-fetal risks, Dark and Campbell (74), recommend: administration of oxygen to the patient during the maneuver, gentle handling and minimization of insufflation pressure, positioning the pregnant woman in the left lateral decubitus to lower the pressure in the inferior vena cava, sedation with meperidine and not with diazepam/midazolam due to the minimal effect on the fetus, fetal cardiac monitoring. Colonoscopy is indicated only in case of CRC suspicion. Recto-sigmoidoscopy or partial colonoscopy is convenient due to the patient's much greater tolerance for exploration, minimal risk for possible congenital malformations or abortion induction, fast and effective, but provides information for lesions up to about $40 \mathrm{~cm}$ from the anocutaneous margin (75-77). However, the risk of leaving synchronous lesions above the distal tumor (5\% of cases), makes rectosigmoidoscopy a "second hand" scan, which can be used whenever we cannot perform a colonoscopy. Therefore, the colonoscopic examination should not stop at the first lesion encountered, and should progress as much as possible. The association of the endoscopic ultrasound examination (intraluminal ultrasound) confers valuable information in assessing the degree of parietal invasion by the tumor. Completing the colonoscopic examination with the cytological examination (brushing of the tumor) or the cells exfoliated from the enema fluid allows the diagnostic index to be increased.

\section{Standard abdominal ultrasound}

Standard abdominal ultrasound has a limited diagnostic role, usually for the assessment of staging ( $\mathrm{M}$ index - metastases): liver metastases (sensitivity of $75-80 \%$ ) or other abdominal disseminations. It can be used to guide needle biopsies (78). Endoscopic ultrasound, especially the transrectal ultrasound, brings additional details for $\mathrm{T}$ (parietal invasion) and $\mathrm{N}$ (lymphadenopathy) indices from TMN staging. The comparison regarding the accuracy in the evaluation of $\mathrm{T}$, on large studies, shows that for CT the value is $75 \%$ and $85 \%$ for echo-endoscopy, respectively (130-138); for $\mathrm{N}$ the values are between $54 \%$ for CT respectively $73 \%$ - $83 \%$ for EUS. In assessing regional lymph node status (N1), recent papers shows a positive predictive value of $86 \%$ (79-83). A special indication of EUS: anterior or large rectal tumors, which can invade the rectum-vaginal septum and vagina, contra-indicating natural birth (84). Whenever the ganglionic aspect of the EUS is abnormal, the guided needle becomes mandatory (EUS FNA) - "gold standard". The combination of the two methods increases the positive prediction factor to $95 \%$. As the distance increases, EUS can no longer provide data, due to low tissue penetrability or, the presence of obstructive tumors (up to $50 \%$ of cases) that cannot be exceeded by the exploratory endoscope, or by the oncological treatments that also interfere with the method (85-87).

\section{Computed tomography}

Essential in assessing the staging of TNM in $\mathrm{CRC}$, the use of CT remains the subject of numerous debates in pregnancy. Of course, whenever the method can be avoided, it is good not to use this technique. If CT can be evocative for a diagnosis, especially in case of a major complication (Fig. 3), or as a therapeutic guide, the practitioner should not hesitate to use it, the life of the mother being considered more valuable than that of the fetus (!). What can CT bring to the assessment of neoplasia during pregnancy? First of all, the appreciation and demonstration of complications that are not apparent or lead to a rapid adverse evolution of the mother in the absence of a clear or obvious diagnosis, which puts her life in immediate danger, especially in the absence of rapid and effective treatment (perforations, obstructions, etc.) $(88,89)$. Secondly, an appreciation of staging. After an initial enthusiasm, in which CT was accredited with an accuracy of $85-90 \%$ in assessing the $\mathrm{T}$ index from TNM staging, high-rigorous studies (90-91) proved a much lower rate, 


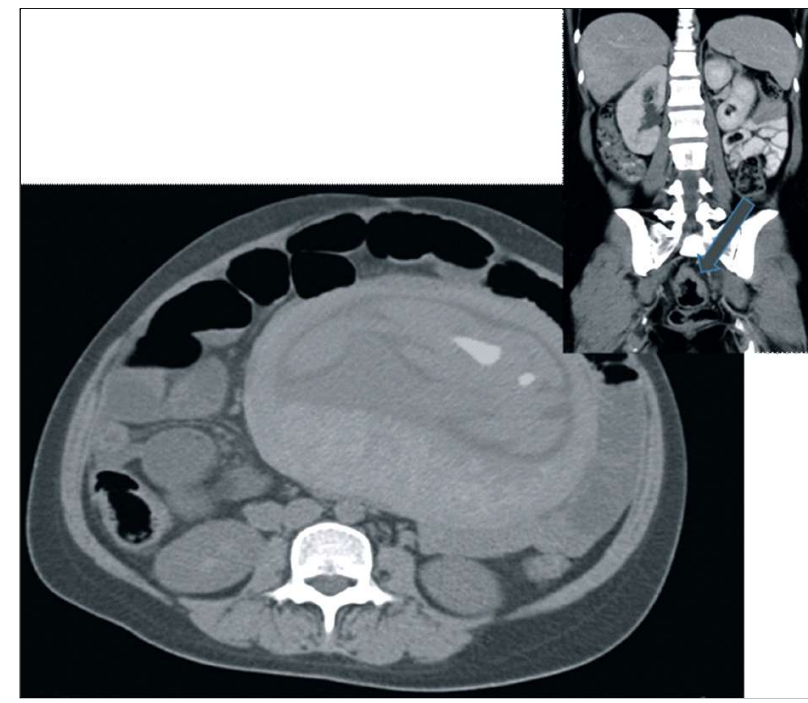

Figure 3. Pregnant CT scan showing an occlusive complication of a recto-sigmoid junction CRC. In cartridge, sagittal section with evidence of a tumor thickening at the level of the recto-sigmoid junction (collection of the clinic)

between $50-70 \%$, dependent of the lesion stage (the accuracy for the T4 lesion is much better compared to that of T2 or T3). Overestimation of the T-index is the most common problem. Particularly for rectal cancer and especially in pregnancy, when zonal changes are important and may alter the accuracy of the method, inflammatory perirectal fibrous bundles may be confused with perirectal tumor infiltration, overestimating the tumor (92). Therefore, the detection of lymphadenopathy ( $\mathrm{N}$ index) remains a problem. That is why the specificity in detection $\mathrm{N}$ is only $45 \%$ (!)(88). The essential role of $\mathrm{CT}$ is to assess the $\mathrm{M}$ index, identifying liver metastases with an accuracy of $85 \%$ and a specificity of $97 \%$ (90). The data are superimposable with those obtained by MRI (91).

Over the last 40 years CT has been contraindicated in pregnant women due to teratogenic and carcinogenic effects on the fetus. The introduction of spiral CT drastically diminished the irradiation during the exploration, and for this reason, the $\mathrm{CT}$ method has been re-evaluated for use in pregnant women. The teratogenic effect of CT radiation is noncumulative (non-stochastic). The most susceptible period to the teratogenic effects of CT irradiation corresponds to the organogenesis period, especially during the 2-15 weeks of pregnancy. Teratogenic complications include (93): mental retardation, growth deficiencies, microcephaly, microphthalmia, behavioral deviations, cataracts. The threshold irradiation dose (94), under which no teratogenic effects occur, it is not clearly known but it appears to be between 5 and 15 cGy. During a spiral CT the dose administered to the fetus is variable (95-98), depending on a number of elements (eg examination parameters), between 2.9-4.4 cGy, irradiating dose well below the critical threshold at congenital malformations (99). The carcinogenic effect over time of CT is cumulative (stochastic), there is no threshold dose. There is also a dependence between the time of radiation exposure in pregnancy and the risk of carcinogenesis. The smaller the pregnancy, the higher the risk (100-101). It is estimated that at the average dose used (2-5 cGy) for a CT, the risk of childhood cancer doubles. However, the value is very low, the recommendations of the American College of Obstetrics and Gynecology are significant: "very low carcinogenic risk, abortion is not recommended" $(97,98,102,103)$.

A problem also arises regarding the use of contrast media. No mutagenic/teratogenic effects were found in the in vivo studies $(104,105)$. The use of iodinated contrast media would have a potential to develop fetal hypothyroidism $(106,107)$ but these reluctances have also been removed by newer studies $(108,109)$, which do not find any side effects in the thyroid function of the child after exposure to them in the fetal period.

A promising option for the evaluation of pregnant women is virtual colonoscopy (CT colonography) due to the use of low doses of irradiation and a reduced "aggressiveness" of the method $(110,111)$. With an excellent accuracy of $81 \%$ and a sensitivity of $93 \%$, the technique will have a lot to say in the future but, for the moment, there are not enough data regarding the application of the method to pregnant women.

\section{Magnetic resonance image}

Magnetic resonance image is the variant used 
in pregnant women instead of CT to assess the stage of CRC. It is considered that regarding the staging indices of remote determinations ( $\mathrm{N}$ and $\mathrm{M}$ ), the method has similar CT limitations but with much higher costs (90). The landmarks to be followed are the same as those in CT exploration. A newer innovation, endoscopic MRI (!), is at least as effective as EUS in assessing parietal tumor invasion (112-113). Some studies find a significant improvement in the accuracy of the T-index assessment, with a sensitivity of $100 \%$ and a specificity of $86 \%$. For $\mathrm{N}$ index (central or intermediate limphatic nodes) the classical MRI is much superior (114-115). MRI also plays an important role $(116,117)$ in accurately predicting circumferential parietal extension (86\%) (sensitivity $94-100 \%$, specificity $85-88 \%$ ) as well as in assessing mesorectal invasion in rectal cancers (118-120), both of which are prognosis and surgical management criteria.

There is a controversy regarding the safety of the method in the case of pregnant women, for possible teratogenic effects of magnetic fields and a possible acoustic damage to the fetus. In vivo studies on animals of Heinrichs et al (121) and Tyndall (122) respectively showed the presence of malformations following exposure to magnetic fields (eg ocular malformations), the death or malformations of embryos when the exam is performed during organogenesis (123). As a result, although no similar effects have been shown in humans, the guidelines of the National Radiological Protection Board from UK (124) recommends: "it is prudent to avoid MRI in pregnant women during the first three months of pregnancy".

The possible acoustic effects induced in the fetus during MRI, are more theoretical, without really constituting an obvious threat (125) and for contrast medium, no teratogenic effects have been reported $(126,127)$. In conclusion, in the first trimester of pregnancy MRI will be performed especially for maternal and less fetal indications. The method is preferable to any other method of investigation that uses ionizing radiation (128).

Regarding other CRC diagnostic methods using nuclear techniques, such as PET-CT, these are not in the current use for assessment in pregnant women but, for selected cases, some specific recommendations can be made (18F-FDG dose reduction, the use of the 3D technique that would allow the decrease of the 18F-FDG dose, a good hydration, attenuation of CT voltage, etc). Technological development has allowed the cumulative radiation doses to the fetus during and after PET-CT to be at absolutely convenient levels (between 1 and 2 cGy), comparable or even lower than those administered by spiral CT (129-130).

\section{Stage and prognosis}

In current practice, several systems for assessing staging (TNM, Duke or modified Astler-Coller) have been developed; however, the most widespread is the one introduced by AJCC and The Union for International Cancer Control (UICC), the TNM system.

\section{Prognosis and evolution}

\section{Maternal prognosis}

The prognosis in CRC in pregnant women targets the two partners: mother and fetus. Maternal prognosis for CRC discovered during pregnancy is poor. This is because the tumor is discovered late, in an advanced stage of the disease. Maybe that's why the prognosis of rectal neoplasia is slightly better than that of colon cancer, because distal malignancy is revealed earlier (see clinical signs) (18). Comparatively, for the same evolutionary stage with the general population, the survival index has no different values (131). In some studies, cases with a 5-year survival are not reported, reinforcing the conclusion of a poor prognosis of CRC in pregnant women (15). Also, Chan et al. (132) on a review of 42 cases of colic cancers found that the vast majority of pregnant women had died 1 year after the time of diagnostic, the average survival period being less than 5 months (!). Only one patient achieved a survival period of 3.5 years and, of all the patients in the literature studied, none survived up to 5 years. For colic tumors, the presence of a chorionic 
gonadotrophin secretion associated with aggressive types of neoplasia was noted: mucinous adenocarcinoma, poorly differentiated or undifferentiated cancer cells, extensive invasion in neighboring organs or distance invasion. Due to these findings, the chain gonadotrophin - aggressive type of cancer unfortunate prognosis in pregnant women is suspected (133-135).

The indices of metastatic invasion (liver, ovary, etc.) are similar to those in the general population, the prognosis being negative (about $1 / 4$ of women with CRC have secondary ovarian determinations) (136-138).

\section{Fetal prognosis}

Hematogenous vertical mother-fetal trans mission appears to be possible but is an exceptional event, the placental barrier and the fetal immune system appear to have a pro- $^{-}$ tective role. Fetal metastases from CRC have not been reported (139-141). More important are the consequences on the fetus after onco-surgical therapies. Induction of malformations, carcinogenic risk, developmental or cerebral disorders, abortion or even fetal death are some of the possible pathologies in therapeutical management; on the other hand, major surgery during pregnancy reports infant mortality rates of about $20 \%(!)(15,142,143)$.

\section{Treatment}

The CRC's treatment plan must take into account the interests of two people, the mother and the fetus, so that the "interest" of one does not affect the other, respecting an axiom: treatment as soon as possible for the mother after a birth as soon as possible for the fetus. Therapeutic protocols undergo changes in terms of the type of therapy, the sequence of methods used and the time to follow. Optimal management requires a multidisciplinary approach oncologist-obstetriciansurgeon-anesthetist-neonatologist and sometimes surgery in mixed teams-obstetriciansurgeon. The family should not be excluded from these decisions, nor should a series of legal, ethical, religious or personal-emotional considerations be neglected.

The essential factors on which the therapeutic protocol to follow depends: tumor location, stage, tumor complications, type of presentation to the doctor (chronic vs. emergency), age of pregnancy and associated pathologies other than cancer, patient's decision $(51,144)$.

Colorectal neoplasia is generally a predominantly surgical pathology at the time of disease discovery, especially in conditions of a major complication that leaves no time for a therapeutic alternative (obstruction, perforation, significant bleeding). The rules of oncological surgery are mandatory: enteral excision depending on the location of the tumor with lymphadenectomy. For right colonic tumors, right ileo-hemicolectomy is performed and for tumors in the left colon, left hemicolectomy, possibly only segmental resection (splenic angle colectomy, sigmoidectomy, recto-sigmoid resection). For low rectal tumors, the most likely technique is that of Miles abdominoperineal resection of the rectum with a definitive left iliac anus.

\section{Diagnosis of neoplasia in the first half of pregnancy}

Diagnosis of neoplasia in the first half of pregnancy, makes ablative surgery necessary, the time too long until the fetus becomes viable substantially increasing the risk of tumor progression. Depending on the tumor stage, abortion to speed up CRC treatment seems to be the option to choose (145). Until 20-30 years ago, the risk of fetal death or abortion was significant after surgical resections (about 25\%), Woods (142) reporting normal newborns in 25 of 32 cases with CRC. Currently, due to the new anesthetic-surgical acquisitions and the laparoscopic approach, the risk of embryo-fetal death has decreased to about 4\%; even the risk of abortion has decreased drastically, yet having a rate twice as high as in the general population (146-149). The risk of malformations is not different from the general population either; however, there is a slightly higher level of low birth weight. 
Particular situations such as invasion of the uterus or a difficult approach in the pelvis may require the operating team to sacrifice the uterus and, of course, the ovaries $(15,146$, 150). In complicated or advanced tumors, palliative techniques such as various bypasses or colostomy may be beneficial, allowing the fetus to reach an age which ensures viability.

\section{Diagnosis of neoplasia in the second half of pregnancy}

The discovery of a CRC between weeks 20-28 most often requires alternative oncological protocols and, only later, once a suitable fetal age is reached, surgery. If the $\mathrm{CRC}$ is apparently localized, with operative perspectives, the operative expectation interval is long enough, about 3 months, which is why chemotherapy is the weapon that represents the solution of a surgical delay. Because at the age of 32-34 weeks the fetus is viable in over $95 \%$ of cases, as much as possible the birth should be provoked in / after this period. After a period of about 7-10 days necessary to reduce pelvic congestion, surgery is performed for tumor ablation, respecting the oncological principles already stated above (151). For CRC ovarectomy is mandatory, the risk of microscopic insemination or remote metastases of Krukenberg type being very high, possibly being recommended to establish with fertility specialists the opportunity of fertility conservation techniques. The existence of particular situations requires the particular protocols. The impossibility of a natural birth, due to a utero-vaginal invasion by a rectal neoplasm with significant invasion to the anterior or a perineotomy with the risk of spreading the neoplasm, require a single operating time, starting by cesarean section and then continued with colorectal resection (51). A chemotherapy-type oncology protocol option is preferred for cases with advanced, metastatic neoplasms, the purpose being obviously to prolong the mother's life until the moment of a "safe" birth. If the fetus is of a suitable age, chemotherapy provides a therapeutic option, although only palliative, to the pregnant woman and the mother in the postpartum period. In the latter situation, the decision of starting the chemotherapy belongs to the mother, who must understand the risks to the fetus, the limited effectiveness of treatment and, of course, take into account a number of moral, religious, ethical, etc. The usual CRC regimens use antimetabolites (5FU, methotrexate, etc.) and alkylating agents (cyclophosphamide, chlorambucil) and the most convenient dual formula, widely used, apparently with minimal effects on the fetus, the combination 5-FU + Leucovorin (folinated calcium) (152). Vinca-derived antibiotics or alkaloids do not cause secondary fetal defects while etoposide induces pancyto-penia and cisplatin hypoacusis or growth retardation. The therapeutic role and side effects of new agents (oxiplatin, irinotecan, capecitabine) are not well explored or documented. For example, Oxiplatin is classified by the FDA in category D toxicity, at risk of fetal injury (153). Fetal toxicity regarding monotherapy vs. polychemotherapy shows a slight increase, from 17 to $25 \%$ in the case of multiple chemotherapy (154). An opion would be the weekly therapy, especially the treatment with doxorubicin, paclitaxel, epirubicin, with minimal hematological effects in the mother and a much faster recovery for childbirth $(155,156)$. Chemotherapy should not be given after 33 weeks or 3 weeks before birth (157).

A particular case is represented by the low rectal cancers, located up to $10 \mathrm{~cm}$ from the ano-cutaneous line. For these, neoadjuvant oncological radiochemotherapy may be a possible solution in pregnant women in the second half of pregnancy. Radiation therapy can induce important side effects: carcinogenesis, mental or physical retardation, even fetal death. New IMRT techniques, with appropriate utero-fetal protection so that the dose of irradiation per pregnancy does not exceed 10 cGy, can provide a therapeutic variant in selected cases (158-160). However, irradiation is recommended in the postpartum period and 
only if it is absolutely necessary during pregnancy, provided that the irradiation area is as far apart as possible from the fetus.

\section{Molecular treatments}

Molecular treatments, such as targeted antiEGFR therapy eg Cetuximab (Erbitux), have not been used and there are no studies to date to provide information on fetal side effects.

\section{Author's Contributions}

Predescu Dragos and Adrian Constantin equal contribution principal authors.

\section{Conflict of Interest}

The authors declare no conflicts of interests.

\section{References}

1. World Health Organization. Ten statistical highlights in global public health. World Health Statistics 2007. Geneva: World Health Organization; 2007.

2. Ferlay J, Shin HR, Bray F, Forman D, Mathers CD, Parkin DM. Estimates of worldwide burden of cancer in 2008: GLOBOCAN 2008. Int J Cancer. 2010;127(12):2893-917.

3. Center MM, Jemal A, Smith RA, Ward E. Worldwide variations in colorectal cancer. CA Cancer J Clin. 2009;59(6):366-378.

4. Center MM, Jemal A, Ward E. International trends in colorectal cancer incidence rates. Cancer Epidemiol Biomarkers Prev. Jun 2009;18(6):1688-1694.

5. Altekruse SF, Kosary CL, Krapcho M, Neyman N, \& all. SEER Cancer Statistics Review, 1975-2007, National Cancer Institute. Bethesda, based on November 2009 SEER data submission, posted to the SEER web site, 2010.

6. Ries L, Melbert D, Krapcho M, et al., editors. SEER Cancer Statistics Review 1975-2005. Bethesda (MD): National Cancer Institute; 2008.

7. Chu KC, Tarone RE, Chow WH, Hankey BF, Ries LAG. Temporal patterns in colorectal cancer incidence, survival, and mortality from 1950 through 1990. J Natl Cancer Inst 1994;86:997-1006.

8. Cress RD, Morris C, Ellison GL, Goodman MT. Secular changes in colorectal cancer incidence by subsite, stage at diagnosis, and race/ ethnicity, 1992-2001. Cancer 2006;107 Suppl 5:1142-52.

9. Phillips KA, Liang SY, Ladabaum U, Haas J, Kerlikowske K, Lieberman $D$, et al. Trends in colonoscopy for colorectal cancer screening. Med Care. 2007;45(2):160-7.

10. Isbister WH, Fraser J. Large-bowel cancer in the young: a national survival study. Dis Colon Rectum. 1990:33;363-366.

11. Nomura A. An international search for causative factors of colorectal cancer. J Natl Cancer Inst. 1990;82(11):894-5.

12. O'Connell JB, Maggard MA, Liu JH, Etzioni DA, Livingston EH, Ko $\mathrm{CY}$. Rates of colon and rectal cancers are increasing in young adults. Am Surg. 2003;69(10):866-72.

13. Siegel $R L$, Jemal A, Ward EM. Increase in Incidence of Colorectal Cancer Among Young Men and Women in the United States. Cancer Epidemiol Biomarkers Prev. 2009;18(6):1695-8.

14. Medich DS, Fazio VW. Hemorrhoids, anal fissure, and carcinoma of the colon, rectum, and anus during pregnancy. Surg Clin North Am. 1995;75(1):77-88

15. Nesbitt JC, Moise KJ, Sawyers JL. Colorectal carcinoma in pregnancy. Arch Surg. 1985;120(5):636-40.

16. Cappell MS. Colon cancer during pregnancy: the gastroenterologist's perspective. Gastroenterol Clin North Am. 1998;27(1):225-56.

17. Minter A, Malik R, Ledbetter L, Winokur TS, Hawn MT, Wasif Saif M. Colon Colon cancer in pregnancy. Cancer Control. 2005;12(3): 196-202.

18. Bernstein MA, Madoff RD, Caushaj PF. Colon and rectal cancer in pregnancy. Dis Colon Rectum. 1993;36(2):172-8.

19. Lichtenstein P, Holm NV, Verkasalo PK, lliadou A, Kaprio J, Koskenvuo M, et al. Environmental and heritable factors in the causation of cancer--analyses of cohorts of twins from Sweden, Denmark, and Finland. N Engl J Med. 2000;343(2):78-85.

20. Aaltonen $L$, Johns $L$, Järvinen $H$, Mecklin JP, Houlston $R$. Explaining the familial colorectal cancer risk associated with mismatch repair (MMR)-deficient and MMR-stable tumors. Clin Cancer Res. 2007;13(1):356-61.

21. Aretz S, Uhlhaas S, Caspari R, Mangold E, Pagenstecher C, Propping $P$, et al. Frequency and parental origin of de novo APC mutations in familial adenomatous polyposis. Eur J Hum Genet. 2004;12(1):52-8.

22. Win AK, Jenkins MA, Buchanan DD, Clendenning M, Young JP, Giles $G G$, et al: Determining the frequency of de novo germline mutations in DNA mismatch repair genes. J Med Genet. 2011; 48(8):530-4.

23. Slattery ML, Samowitz WS, Holden JA. Estrogen and progesterone receptors in colon tumors. Am J Clin Pathol. 2000;113(3):364-8.

24. Korenaga $D$, Orita $\mathrm{H}$, Maekawa $\mathrm{S}$, Itasaka $\mathrm{H}$, Ikeda T, Sugimachi $\mathrm{K}$. Relationship between hormone receptor levels and cell-kinetics in human colorectal cancer. Hepatogastroenterology. 1997;44(13): 78-83.

25. Majerus PW. Prostaglandins: critical roles in pregnancy and colon cancer. Curr Biol. 1998;8(3):R87-9.

26. Flegal KM, Carroll MD, Kuczmarski RJ, Johnson CL. Overweight and obesity in the United States: prevalence and trends, 19601994. Int J Obes Relat Metab Disord. 1998;22(1):39-47.

27. Ogden CL, Carroll MD, Curtin LR, McDowell MA, Tabak CJ, Flegal $\mathrm{KM}$. Prevalence of overweight and obesity in the United States, 1999-2004. JAMA. 2006;295(13):1549-55

28. Larsson SC, Orsini N, Wolk A. Diabetes mellitus and risk of colorectal cancer: a meta-analysis. J Natl Cancer Inst. 2005;97(22): 1679-87.

29. Engelgau MM, Geiss LS, Saaddine JB, Boyle JP, Benjamin SM, Gregg EW, et al. The evolving diabetes burden in the United States. Ann Intern Med. 2004;140(11):945-50.

30. Larsson SC, Wolk A. Meat consumption and risk of colorectal cancer: a meta-analysis of prospective studies. Int J Cancer. 2006; 119(11):2657-64.

31. Guthrie JF, Lin BH, Frazao E. Role of food prepared away from home in the American diet, 1977-78 versus 1994-96: changes and consequences. J Nutr Educ Behav. 2002;34(3):140-50.

32. Pereira MA, Kartashov Al, Ebbeling CB, Van Horn L, Slattery ML, Jacobs DR Jr, et al. Fast-food habits, weight gain, and insulin resistance (the CARDIA study): 15-year prospective analysis. Lancet. 2005;365(9453):36-42.

33. Ferrari $P$, Jenab $M$, Norat $T$, Moskal A, Slimani N, Olsen A, et al. Lifetime and baseline alcohol intake and risk of colon and rectal cancers in the European prospective investigation into cancer and nutrition (EPIC). Int J Cancer. 2007;121(9):2065-72.

34. Botteri E, lodice S, Bagnardi V, Raimondi S, Lowenfels AB, Maisonneuve P. Smoking and colorectal cancer: a meta-analysis. JAMA. 2008;300(23):2765-78.

35. Eaden JA, Abrams KR and Mayberry JF: The risk of colorectal cancer in ulcerative colitis: a meta-analysis. Gut. 2001;48(4):526-35

36. Lakatos PL, Lakatos L. Risk for colorectal cancer in ulcerative colitis: changes, causes and management strategies. World $\mathrm{J}$ Gastroenterol. 2008;14(25):3937-47.

37. Bernstein CN, Blanchard JF, Kliewer E, Wajda A. Cancer risk in 
patients with inflammatory bowel disease: a population based study. Cancer. 2001;91(4):854-62.

38. von Roon AC, Reese G, Teare J, Constantinides V, Darzi AW, Tekkis PP. The risk of cancer in patients with Crohn's disease. Dis Colon Rectum. 2007;50(6):839-55.

39. Hamilton SR, Bosman FT, Boffetta P, et al. Carcinoma of the colon and rectum. In: WHO Classification of Tumours of the Digestive System. Bosman FT, Carneiro F, Hruban RH, Theise ND, eds. Lyon: IARC Press; 2010. p. 134-46.

40. Jass JR. Classification of colorectal cancer based on correlation of clinical, morphological and molecular features. Histopathology. 2007;50(1):113-30

41. DiSario JA, Burt RW, Kendrick ML, McWhorter WP. Colorectal cancers of rare histologic types compared with adenocarcinomas. Dis Colon Rectum. 1994;37(12):1277-80.

42. Oh K, Redston M, Odze RD. Support for hMLH1 and MGMT silencing as a mechanism of tumorigenesis in the hyperplastic-adenomacarcinoma (serrated) carcinogenic pathway in the colon. Hum Pathol. 2005;36(1):101-11.

43. Rubin CE, Bronner MP. Endoscopic mucosal biopsy: a memorial to Rodger C. Haggitt, M.D. In: Yamada T, Alpers D, Kaplowitz N, et al, editors. Textbook of gastroenterology. 4th edition. Philadelphia: Lippincott Williams \& Wilkins; 2003. p. 2893-946.

44. Schlemper RJ, Riddell RH, Kato Y, Borchard F, Cooper HS, Dawsey $\mathrm{SM}$, et al. The Vienna classification of gastrointestinal epithelia neoplasia. Gut. 2000; 47(2):251-5

45. Frank R, Saclarides T, Leurgans S, Speziale NJ, Drab EA, Rubin DB Tumor angiogenesis as a predictor of recurrence and survival in patients with node-negative colon cancer. Ann Surg. 1995;222(6) 695-9.

46. Mulcahy HE, Skelly MM, Husain A, O'Donoghue DP. Long-term outcome following curative surgery for malignant large bowel obstruction. Br J Surg. 1996;83(1):46-50.

47. Roncucci L, Fante R, Losi L, Di Gregorio C, Micheli A, Benatti P, et al. Survival for colon and rectal cancer in a population-based cancer registry. Eur J Cancer. 1996;32A(2):295-302.

48. Takebayashi Y, Akiyama S, Yamada K, Akiba S, Aikou T. Angiogenesis as an unfavorable prognostic factor in human colorectal carcinoma. Cancer. 1996;78(2):226-31.

49. Deans GT, Patterson CC, Parks TG, Spence RA, Heatley M Moorehead RJ, et al. Colorectal carcinoma: importance of clinica and pathological factors in survival. Ann R Coll Surg Engl. 1994; 76(1):59-64.

50. Surbone A, Peccatori F, Pavlidis N. Cancer and Pregnancy. BerlinHeidelberg-New York: Springer ;2008, p: 137-165

51. Walsh C, Fazio VW. Cancer of the colon, rectum, and anus during pregnancy: the surgeon's perspective. Gastroenterol Clin North Am. 1998:27(1):257-67.

52. Harewood GC, Ahlquist DA. Fecal occult blood testing for iron deficiency: a reappraisal. Dig Dis. 2000;18(2):75-82.

53. Predescu D. Surgical pathology. In Chapter "Colic cancer". Bucuresti: Ed. University "Carol Davila"; 2003. p: 30-46.

54. Macrae FA, St. John DJ. Relationship between patterns of bleeding and Hemoccult sensitivity in patients with colorectal cancers or adenomas. Gastroenterology. 1982;82(5 Pt 1):891-8.

55. Helm JF, Sandler RS. Colorectal cancer screening. Med Clin North Am. 1999:83:39-44.

56. McDonnell WM, Ryan JA, Seeger DM, Elta GH. Effect of iron on the guaiac reaction. Gastroenterology. 1989;96(1):74-8.

57. Simon JB. Fecal occult blood testing: clinical value and limitations Gastroenterologist. 1998;6(1):66-78.

58. William F. Baker Jr. Iron deficiency in pregnancy, obstetrics, and gynecology. Hematol Oncol Clin North Am. 2000;14(5):1061-77.

59. Rockey DC. Occult gastrointestinal bleeding. N Engl J Med. 1999; 341(1):38-46

60. Nagai $Y$, Beppu T, Sakamoto $Y$, Miyamoto $Y$, Hayashi $H$, Nitta $H$, et al. Carcinoembryonic antigen half-life is an early predictor of therapeutic effects in induction chemotherapy for liver metastases from colorectal cancer. Anticancer Res. 2014;34(10):5529-35.

61. Macdonald JS. Carcinoembryonic antigen screening: pros and cons. Semin Oncol. 1999;26(5):556-60.

62. Palmqvist R, Engaras B, Lindmark G, Hallmans G, Tavelin B, Nilsson 0, et al: Prediagnostic levels of carcinoembryonic antigen and CA 242 in colorectal cancer: A matched casecontrol study. Dis Colon Rectum. 2003;46(11):1538-44.

63. Duffy MJ, van Dalen A, Haglund C, Hansson L, Klapdor R, Lamerz $R$, et al. Clinical utility of biochemical markers in colorectal cancer: European Group on Tumour Markers (EGTM) guidelines. Eur J Cancer. 2003;39(6):718-27

64. Lamerz R, Ruider H. Significance of CEA determinations in patients with cancer of the colon-rectum and the mammary gland in comparison to physiological states in connection with pregnancy. Bull Cancer. 1976;63(4):575-86

65. Locker GY, Hamilton S, Harris J, Jessup JM, Kemeny N, Macdonald JS, et al. ASCO 2006 update of recommendations for the use of tumor markers in gastrointestinal cancer $\mathrm{J}$ Clin Oncol. 2006;24(33):5313-27.

66. Lennon T, Houghton J, Northover JM, et al. What is the value of clinical follow-up for colorectal cancer patients? The experience of the CRC/NIH CEA second-look trial - proceedings of the Nottingham International Colorectal Cancer Symposium. Nottingham, 1995 (abstr).

67. Northover J, Houghton J, Lennon T. CEA to detect recurrence of colon cancer. JAMA. 1994;272(1):31.

68. Pentheroudakis G, Pavlidis N, Castiglione M. Cancer, fertility and pregnancy: ESMO Clinical Recommendations for diagnosis, treatment and follow-up On behalf of the ESMO Guidelines Working. Group Annals of Oncology. 2009;20 (Supplement 4): iv178-iv181.

69. Streffer C, Shore R, Konermann G, Meadows A, Uma Devi P, Preston Withers J, et al. Biological effects after prenatal irradiation (embryo and fetus). A report of the International Commission on Radiological Protection. Ann ICRP. 2003;33(1-2):5-206.

70. Rex DK, Rahmani EY, Haseman JH, Lemmel GT, Kaster S, Buckley JS. Relative sensitivity of colonoscopy and barium enema for detection of colorectal cancer in clinical practice. Gastroenterology. 1997:112(1):17-23.

71. Blakeborough A, Sheridan MB, Chapman AH. Complications of barium enema examinations: a survey of UK consultant radiologists 1992 to 1994. Clin Radiol. 1997;52(2):142-8.

72. Cappell MS. Gastrointestinal endoscopy in high risk patients. Dig Dis. 1996;14(4):228-44.

73. Melmed AD. Anesthesia principles and techniques in pregnancy. In: Cherr ST, Merkatz IR, eds. Complications of Pregnancy: Medical, Surgical, Gynecologic, Psychosocial, and Perinatal. 4th ed. Baltimore, Md: Williams and Wilkins; 1991.

74. Cappell MS, Colon VJ, Sidhom OA. A study of eight medical centers of the safety and clinical efficacy of esophagogastroduodenoscopy in 83 pregnant females with follow-up of fetal in 83 pregnant females with follow-up of fetal outcome and with comparison control groups. Am J Gastroenterol. 1996;91(2):348-54.

75. Cappell MS. The fetal safety and clinical efficacy of gastrointestinal endoscopy during pregnancy. Gastroenterol Clin North Am. 2003; 32(1):123-79.

76. Cappell MS, Colon VJ, Sidhom OA. A study at 10 medical centers of the safety and efficacy of 48 flexible sigmoidoscopies and 8 colonoscopies during pregnancy with follow-up of fetal outcome and with comparison to control groups. Dig Dis Sci. 1996;41(12): 2353-61.

77. Yaghoobi M, Koren G, Nulman I. Challenges to diagnosing colorectal cancer during pregnancy. Can Fam Physician. 2009;55(9):881-5.

78. Nies C, Leppek R, Sitter H, Klotter HJ, Riera J, Klose KJ, et al. Prospective evaluation of different diagnostic techniques for the detection of liver metastases at time of primary resection of colorectal carcinoma. I Eur J Surg. 1996;162(10):811-6. 
79. Marone P, Petrulio F, de Bellis M, Battista Rossi G, Tempesta A. Role of endoscopic ultrasonography in the staging of rectal cancer: a retrospective study of 63 patients. J Clin Gastroenterol. 2000; 30(4):420-4.

80. Gualdi GF, Casciani E, Guadalaxara A, d'Orta C, Polettini E, Pappalardo G. Local staging of rectal cancer with transrectal ultrasound and endorectal magnetic resonance imaging: comparison with histologic findings. Dis Colon Rectum. 2000;43(3):338-45.

81. Kim JC, Kim HC, Yu CS, Han KR, Kim JR, Lee KH, Jang SJ, Lee SS, Ha HK Efficacy of 3-dimensional endorectal ultrasonography compared with conventional ultrasonography and computed tomography in preoperative rectal cancer staging.Am J Surg. 2006 Jul;192(1):89-97.

82. Marone P, Petrulio F, de Bellis M, Battista Rossi G, Tempesta A. Role of endoscopic ultrasonography in the staging of rectal cancer: a retrospective study of 63 patients. J Clin Gastroenterol. 2000; 30(4):420-4.

83. Badger SA, Devlin PB, Neilly PJ, Gilliland R. Preoperative staging of rectal carcinoma by endorectal ultrasound: is there a learning curve? Int J Colorectal Dis. 2007;22(10):1261-8. Epub 2007 Feb 9.

84. Spinelli P, Schiavo M, Meroni E, Di Felice G, Andreola S, Gallino G, et al: Results of EUS in detecting perirectal lymph node metastases of rectal cancer: The pathologist makes the difference. Gastrointest Endosc. 1999:49(6):754-8.

85. Schwartz DA, Harewood GC, Wiersema MJ. EUS for rectal disease Gastrointest Endosc. 2002;56(1):100-9.

86. Santiago RJ. Metz JM, Hahn S. Chemoradiotherapy in the treatment of rectal cancer. Hematol Oncol Clin North Am. 2002;16(4): 995-1014, viii.

87. Bernini A, Deen KI, Madoff RD, Wong WD. Preoperative adjuvant radiation with chemotherapy for rectal cancer: its impact on stage of disease and the role of endorectal ultrasound. Ann Surg Oncol. 1996;3(2):131-5

88. Thoeni RF. Colorectal cancer. Radiologic staging. Radiol Clin North Am. 1997;35(2):457-485.

89. Farouk R, Nelson H, Radice E, Mercill S, Gunderson L. Accuracy of computed tomography in determining resectability for locally advanced primary or recurrent colorectal cancers. Am J Surg. 1998; 175(4):283-287

90. Zerhouni EA, Rutter C, Hamilton SR, D M Balfe, Megibow AJ, Francis IR, et al. CT and MR imaging in the staging of colorectal carcinoma: report of the Radiology Diagnostic Oncology Group II. Radiology. 1996;200(2):443-51.

91. Bhattacharjya S, Bhattacharjya T, Baber S, Tibballs JM, Watkinson AF, Davidson BR. Prospective study of contrast-enhanced computed tomography, computed tomography during arterioportography, and magnetic resonance imaging for staging colorectal liver metastases for liver resection. Br J Surg. 2004;91(10):1361- 1369.

92. Low G, Tho LM, Leen E, Wiebe E, Kakumanu S, McDonald AC, et al. The role of imaging in the pre-operative staging and postoperative follow-up of rectal cancer. Surgeon. 2008;6(4):222-31.

93. Wagner LK, Lester RG, Saldana LR. Exposure of the pregnant patient to diagnostic radiations: a guide to medical management. Philadelphia; Lippincott 1985; 19-223

94. Berlin L. Radiation exposure and the pregnant patient. AJR Am J Roentgenol. 1996;167(6):1377-9.

95. Damilakis J, Perisinakis K, Voloudaki A, Gourtsoyiannis N. Estimation of fetal radiation dose from computed tomography scanning in late pregnancy: depth-dose data from routine examinations. Invest Radiol. 2000;35(9):527-33.

96. Goldberg-Stein S, Liu B, Hahn PF, Lee SI. Body CT during pregnancy: utilization trends, examination indications, and fetal radiation doses. AJR Am J Roentgenol. 2011;196(1):146-51.

97. Ratnapalan S, Bona N, Chandra K, Koran G. Physicians' perceptions of teratogenic risk associated with radiography and $\mathrm{CT}$ during early pregnancy. AJR Am J Roentgenol. 2004;182(5):1107-9.

98. Bentur Y. Ionizing and nonionizing radiation in pregnancy. In: Koren
G, ed. Maternal-fetal toxicology: a clinician's guide, 3rd ed. New York, NY: Marcel Dekker; 2001. p. 603-651.

99. Mole RH. Irradiation of the embryo and fetus. $\mathrm{Br} J$ Radiol. 1987; 60(709):17-31.

100. Doll R, Wakeford R. Risk of childhood cancer from fetal irradiation. Br J Radiol. 1997;70:130-9.

101. Gilman EA, Kneale GW, Knox EG, Stewart AM. Pregnancy X-rays and childhood cancers: effects of exposure age and radiation dose. J Radiol Prot 1988;8:3-8.

102. ACOG Committee on Obstetric Practice. ACOG Committee Opinion. Number 299, September 2004. Guidelines for diagnostic imaging during pregnancy. Obstet Gynecol. 2004;104(3):647-51.

103. Goldberg-Stein SA, Liu B, Hahn PF, Lee SI. Radiation dose management: part 2, estimating fetal radiation risk from CT during pregnancy. AJR Am J Roentgenol. 2012;198(4):W352-6.

104. Morisetti A, Tirone P, Luzzani F, de Haen C. Toxicologic safety assessment of iomeprol, a new x-ray contrast agent. Eur J Radiol 1994;18 (Suppl 1):21-31.

105. Ralston WH, Robbins MS, James P. Reproductive, developmental, and genetic toxicity of ioversol. Invest Radiol 1989; 24 (Suppl 1): 16-22.

106. Rodesch F, Camus M, Ermans AM, Dodion J, Delange F. Adverse effects of amniofetography on fetal thyroid function. Am J Obstet Gynecol. 1976;126(6):723-6.

107. Bona G, Zaffaroni M, Defilippi C, M R Gallina, M Mostert. Effects of iopamidol on neonatal thyroid function. Eur J Radiol. 1992;14(1): $22-5$

108. Atwell TD, Lteif AN, Brown DL, McCann M, Townsend JE, Andrew J. LeRoy neonatal thyroid function after administration of IV iodinated contrast agent to 21 pregnant patients. Women's Imaging. 2008; 191(1):268-271.

109. Webb JA, Thomsen HS, Morcos SK; Members of Contrast Media Safety Committee of European Society of Urogenital Radiology (ESUR). The use of iodinated and gadolinium contrast media during pregnancy and lactation. Eur Radiol. 2005:15(6):1234-40.

110. Morrin MM, Farrell RJ, Raptopoulos V, McGee JB, Bleday R, Kruskal JB. Role of virtual computed tomographic colonography in patients with colorectal cancers and obstructing colorectal lesions. Dis Colon Rectum. 2000;43(3):303-311.

111. Halligan S, Altman DG, Taylor SA, Susan Mallett, Deeks JJ, Bartram $\mathrm{Cl}$, et al. CT colonography in the detection of colorectal polyps and cancer: systematic review, meta-analysis, and proposed minimum data set for study level reporting. Radiology. 2005;237(3):893-904

112. Kim SH, Lee JM, Lee MW, Kim GH, Han JK, Choi BI. Diagnostic accuracy of 3.0-Tesla rectal magnetic resonance imaging in preoperative local staging of primary rectal cancer. Invest Radiol. 2008;43(8):587-593.

113. Wong EM, Leung JL, Cheng CS, Lee JC, Li MK, Chung CC. Effect of endorectal coils on staging of rectal cancers by magnetic resonance imaging. Hong Kong Med J. 2010;16(6):421-426

114. Vogl TJ, Pegios W, Mack MG, Rausch M, Hintze H, Hünerbein M, et al. Radiological modalities in the staging of colorectal tumors: new perspectives for increasing accuracy. Recent Results Cancer Res. 1996;142:103-20.

115. Zagoria RJ, Schlarb CA, Ott DJ, Bechtold RI, Wolfman NT, Scharling ES, et al. Assessment of rectal tumor infiltration utilizing endorectal MR imaging and comparison with endoscopic rectal sonography. J Surg Oncol. 1997;64(4):312-7.

116. Videhult $\mathrm{P}$, Smedh $\mathrm{K}$, Lundin $\mathrm{P}$, Kraaz W. Magnetic resonance imaging for preoperative staging of rectal cancer in clinical practice: high accuracy in predicting circumferential margin with clinical benefit. Colorectal Dis. 2007:9(5):412-419.

117. Purkayastha S, Tekkis PP, Athanasiou T, Tilney HS, Darzi AW, Heriot AG. Diagnostic precision of magnetic resonance imaging for preoperative prediction of the circumferential margin involvement in patients with rectal cancer. Colorectal Dis. 2007;9(5):402-411. 
118. Extramural depth of tumor invasion at thin-section MR in patients with rectal cancer: results of the MERCURY study. Radiology. 2007;243(1):132-139

119. Kim SH, Lee JM, Park HS, Eun HW, Han JK, Choi BI. Accuracy of MR for predicting the circumferential resection margin, mesorectal fascia invasion, and tumor response to neoadjuvant hemoradiotherapy for locally advanced rectal cancer. J Magn Reson Imaging. 2009;29(5): 1093-1101.

120. Wieder HA, Rosenberg R, Lordick F, Geinitz H, Beer A, Becker K, et al. Rectal cancer: MR imaging before neoadjuvant chemotherapy and radiation therapy for prediction of tumor-free circumferential resection margins and long-term survival. Radiology. 2007;243(3): 744-51

121. Heinrichs WL, Fong $P$, Flannery $M$, Heinrichs SC, Crooks LE Spindle A, et al. Midgestational exposure of pregnant balb/c mice to magnetic resonance imaging. Mag Res Imag. 1986;8:65-69.

122. Tyndall DA, Sulik KK. Effects of magnetic resonance imaging on eye development in the C57BL/6J mouse. Teratology. 1991;43(3): 263-75.

123. Yip YP, Capriotti C, Talagala SL, Yip JW. Effects of MR exposure at $1.5 \mathrm{~T}$ on early embryonic development of the chick. J Magn Reson Imaging. 1994;4(5):742-8.

124. National Radiological Protection Board. Principles for the Protection of Patients and Volunteers During Clinical Magnetic Resonance Diagnostic Procedures. Documents of the NRPB. Volume 2, no 1. London: HM Stationery Office, 1991.

125. Gover P, Hykin J, Gowland P, Wright J, Johnson I, Mansfield P. An assessment of the intrauterine sound intensity level during obstetric echo-planar magnetic resonance imaging. $\mathrm{Br} J$ Radiol. 1995 68(814):1090-4

126. Marcos HB, Semelka RC, Worawattanakul S. Normal placenta: gadolinium-enhanced dynamic MR imaging. Radiology. 1997; 205(2):493-6.

127. Spencer JA, Tomlinson AJ, Weston MJ, Lloyd SN. Early report: comparison of breath-hold MR excretory urography, Doppler ultrasound and isotope renography in evaluation of symptomatic hydronephrosis in pregnancy. Clin Radiol. 2000;55(6):446-53.

128. Shellock FG, Kanal E. Policies, guidelines, and recommendations for MR imaging safety and patient management. J Magn Reson Imaging. 1991;1(1):97-101.

129. Zanotti-Fregonara $P$, Jan S, Taieb D, Cammilleri S, Trébossen $R$, Hindié $\mathrm{E}$, et al. Absorbed 18F-FDG dose to the fetus during early pregnancy. J Nucl Med. 2010;51(5):803-5.

130. Takalkar AM, Khandelwal A, Lokitz S, Lilien DL, Stabin MG. 18F-FDG PET in pregnancy and fetal radiation dose estimates. J Nucl Med. 2011;52(7):1035-40.

131. Dunkelberg JC, Barakat J, Deutsch J. Gastrointestinal, pancreatic and hepatic cancer during pregnancy. Obstet Gynecol Clin North Am. 2005;32(4):641-60.

132. Chan YM, Ngai SW, Lao TT. Colon cancer in pregnancy: a case report. J Reprod Med. 1999;44(8):733-6.

133. Krause $H$, Watt $A$. Positive pregnancy test in a patient with colorectal carcinoma. Aust N Z J Obstet Gynaecol. 2003;43(3):241-2.

134. Campo E, Palacin A, Benasco C, Quesada E, Cardesa A. Human chorionic gonadotropin in colorectal carcinoma: an immunohistochemical study. Cancer. 1987;59(9):1611-6.

135. Skinner JM, Whitehead R. Tumor-associated antigens in polyps and carcinoma of the human large bowel. Cancer. 1981;47:1241-5.

136. Mason MH, Kovalcik PJ. Ovarian metastases from colon carcinoma. J Surg Oncol. 1981;17(1):33-8.

137. Pitluk H, Poticha SM. Carcinoma of the colon and rectum in patients less than 40 years of age. Surg Gynecol Obstet. 1983; 157(4):335-7.

138. Matsuyama T, Tsukamoto N, Matsukuma K, Kamura T, Kaku T,
Saito T. Malignant ovarian tumors associated with pregnancy: report of six cases. Int J Gynaecol Obstet. 1989;28(1):61-6.

139. Cappell MS. Colon cancer during pregnancy. Gastroenterol Clin North Am. 2003;32(1):341-83.

140. Nicholas A. Coexistence of pregnancy and malignancy. Oncologist. 2002;7(4):279-87.

141. Barber HR. Malignant disease in pregnancy. J Perinat Med. 2001; 29(2):97-111.

142. Woods JB, Martin JN, Ingram FH, Odom CD, Scott-Conner CE, Rhodes RS. Pregnancy complicated by carcinoma of the colon above the rectum. Am J Perinatol. 1992;9(2):102-10.

143. Hill JA, Kassam SH, Talledo OE. Colonic cancer in pregnancy. South Med J. 1984;77(3):375-8

144. Savlovschi C, Serban D, Trotea T, Borcan R, Dumitrescu D. Postsurgery morbidity and mortality in colorectal cancer in elderly subjects. Chirurgia (Bucur). 2013;108(2):177-9.

145. Arbman G, Nilsson E, Storgren-Fordell V, Sjödahl R. A short diagnostic delay is more important for rectal cancer than for colonic cancer. Eur J Surg. 1996;162(11):899-904.

146. Skilling JS Colorectal cancer complicating pregnancy. Obstet Gynecol Clin North Am. 1998;25(2):417-21.

147. Curet MJ, Allen D, Josloff RK, Pitcher DE, Curet LB, Miscall BG, et al. Laparoscopy during pregnancy. Arch Surg. 1996;131(5):54650; discussion 550-1.

148. Rizzo AG. Laparoscopic surgery in pregnancy: long-term follow up. J Laparoendosc Adv Surg Tech A. 2003;13(1):11-5.

149. Lemaire BM, van Erp WR. Laparoscopic surgery during pregnancy. Surg Endosc. 1997;11(1):15-8.

150. Fetus and Newborn Committee, Canadian Paediatric Society, Maternal-Fetal Medicine Committee, Society of Obstetricians and Gynaecologists of Canada. Management of the woman with threatened birth of an infant of extremely low gestational age. CMAJ. 1994:151(5):547-53.

151. Malangoni MA. Gastrointestinal surgery and pregnancy. Gastroenterol Clin North Am. 2003;32(1):181-200.

152. Briggs GG, Freeman RK, Yaffe SJ. Folic acid. Drugs in pregnancy and lactation: a reference guide to fetal and neonatal risk. Philadelphia: Lippincott Williams Wilkins; 2002. p. 583-597.

153. Minter A, Malik R, Ledbetter L, Winokur TS, Hawn MT, Wasif Saif M. Colon cancer in pregnancy. Cancer Control. 2005;12(3):196-202.

154. Doll DC, Ringenberg QS, Yarbro JW. Antineoplastic agents and pregnancy. Semin Oncol. 1989;16(5):337-46.

155. Ellis GK, Barlow WE, Gralow JR, Hortobagyi GN, Russell CA, Royce ME, et al. Phase III comparison of standard doxorubicin and cyclophosphamide versus weekly doxorubicin and daily oral cyclophosphamide plus granulocyte colony-stimulating factor as neoadjuvant therapy for inflammatory and locally advanced breast cancer: SWOG 0012. J Clin Oncol. 2011;29(8):1014-21.

156. Sparano JA, Wang M, Martino S, Jones V, Perez EA, Saphner T, et al. Weekly paclitaxel in the adjuvant treatment of breast cancer. $\mathrm{N}$ Engl J Med. 2008;358(16):1663-71.

157. Aytac E, Ozuner G, Isik O, Gorgun E, Stocchi L. Management of colorectal neoplasia during pregnancy and in the postpartum period. World J Gastrointest Oncol. 2016;8(7):550-4

158. Spanheimer PM, Graham MM, Sugg SL, Scott-Conner CEH, Weigel RJ. Measurement of uterine radiation exposure from lymphoscintigraphy indicates safety of sentinel lymph node biopsy during pregnancy. Ann Surg Oncol. 2009;16(5):1143-7.

159. Jeppesen JB, Østerlind K. Successful twin pregnancy outcome after in utero exposure to FOLFOX for metastatic colon cancer: a case report and review of the literature. Clin Colorectal Cancer. 2011;10(4):348-52

160. Morice $P$, Uzan C, Uzan S. Cancer in pregnancy: a challenging conflict of interest. Lancet. 2012;379(9815):495-6. 